\title{
KARSINOMA ADENOSKUAMOSA ENDOMETRIUM
}

\author{
Lily Loho \\ Bagian Patologi Antomi Fakultas Kedokteran Universitas Sam Ratulangi \\ e-mail: lily_loho@yahoo.com
}

\begin{abstract}
Adenocarcinoma of the endometrium frequently contains foci of squamous metaplasia. If the squamous component is benign, it is called adenoacanthoma. On the other hand, if the squamous component is malignant, it is called adenosquamous carcinoma, which grows much more aggressively. The prognosis of adenoacanthoma does not differ significantly from that of pure adenocarcinoma. In the United States the incidence of adenosquamous carcinoma of the endometrium is still high, while in the Pathology Laboratory of the Medical Faculty, University of Sam Ratulangi, Manado this type is very rarely identified. We reported a case of adenosquamous carcinoma of the endometrium in a 53-year-old female that had undergone a radical hysterectomy due to a clinical diagnosis of uterine myoma and a pathologic diagnosis of nonkeratinizing squamous cell carcinoma for which she underwent an endometrial curettage three weeks before. After the operation, the final diagnosis of this case was adenosquamous carcinoma of the endometrium type I, grade two, with deep invasion into myometrium. There was no invasion into other tissues and no metastasis to lymph nodes. The prognosis of this case was good.
\end{abstract}

Keywords: endometrial carcinoma, adenosquamous, clasificassion

\begin{abstract}
Abstrak: Karsinoma endometrium (KE) sering mengandung fokus-fokus metaplasia skuamosa. Bila komponen skuamosa jinak disebut adenoakantoma, yang prognosisnya tidak berbeda bermakna dengan bentuk murni adenokarsinoma. Bila komponen tersebut ganas disebut karsinoma adenoskuamosa, dengan pertumbuhan yang lebih agresif. Di Amerika Serikat insiden KE adenoskuamosa masih tinggi, sedangkan di Laboratorium Patologi Fakultas Kedokteran Universitas Sam Ratulangi Manado jenis ini sangat jarang ditemukan. Kami melaporkan sebuah kasus KE adenoskuamosa seorang perempuan berusia 53 tahun yang telah dilakukan histerektomi radikal dengan diagnosis klinis mioma uteri dan diagnosis patologik karsinoma sel skuamosa tanpa keratinisasi dari hasil kerokan endometrium tiga minggu sebelumnya. Diagnosis akhir kasus ini adalah KE adenoskuamosa tipe I, derajat dua, dengan invasi ke lapisan dalam miometrium. Tidak ditemukan invasi ke jaringan lain atau metastasis ke kelenjar getah bening. Prognosis kasus ini cukup baik.
\end{abstract}

Kata kunci: karsinoma endometrium, adenoskuamosa, klasifikasi

Karsinoma endometrium (KE) adalah keganasan ginekologi yang paling umum di negara maju, dan merupakan keganasan terbanyak ke empat setelah payudara, paru, dan usus. Insiden tertinggi di Amerika Serikat dan Kanada, tetapi dalam tahuntahun terakhir ini terdapat kecenderungan penurunan insidens dan mortalitas. Penyakit ini khas ditemukan pada orang tua, dimana sekitar $80 \%$ pasien telah pasca menopause pada saat didiagnosis. Walaupun demikian penyakit ini dapat juga terjadi pada kelompok umur yang lebih muda, serta telah dilaporkan hubungannya dengan kehamilan 
intrauterin $^{1-4}$

Berdasarkan patogenesis $\mathrm{KE}$ dibagi atas dua jenis: tipe I, jenis yang paling umum terjadi pada perempuan yang berusia lebih muda, perimenopause, dengan riwayat paparan estrogen baik endogen atau eksogen. Pada individu ini tumor berawal sebagai hiperplasia endometrium dan kemudian berkembang menjadi karsinoma. Tumor estrogen dependent ini cenderung berdiferensiasi lebih baik dengan prognosis yang lebih baik pula dibandingkan dengan tumor yang tidak berhubungan dengan hiperestrogen. Jenis lainnya, tipe II terjadi pada perempuan tanpa stimulasi estrogen pada endometrium. Tipe ini terjadi spontan, tidak berhubungan dengan hiperplasia endometrium, tetapi dapat muncul pada latar belakang kelenjar endometrium yang atrofi. Tumor ini kurang berdiferensiasi, dan dihubungkan dengan prognosis yang lebih jelek dari pada tumor estrogen dependent, terjadi pada perempuan berusia lebih tua, pasca menopause, dan bertubuh kurus. Bentuk histologik jenis ini adalah karsinoma serosa dan karsinoma clear cell (karsinoma sel jernih). ${ }^{3-5}$

Selain berdasarkan patogenesis, juga terdapat klasifikasi $\mathrm{KE}$ secara histologik yaitu: adenokarsinoma endometrioid, karsinoma musinosa, karsinoma serouspapiliferum, karsinoma sel jernih, karsinoma skuamosa, karsinoma tidak berdiferensiasi, dan karsinoma bentuk campuran. Pada KE sering terdapat fokus metaplasia skuamosa; bila jinak disebut adenoakantoma yang secara umum mempunyai prognosis yang tidak berbeda secara bermakna dengan adenokarsinoma. Bila fokus skuamosa ganas maka disebut karsinoma adenoskuamosa. Istilah umum untuk kedua jenis $\mathrm{KE}$ ini adalah adenokarsinoma dengan diferensiasi skuamosa., ${ }^{5,6}$ Di Amerika Serikat bentuk keganasan ini masih tinggi dan dewasa ini mencapai sekitar sepertiga dari kasus tumor ganas endometrium. Tingginya insidens penyakit ini mendapat perhatian khusus karena mempunyai prognosis yang mungkin lebih buruk dari bentuk adenokarsinoma. ${ }^{5} \mathrm{Di}$ Laboratorium Patologi Fakultas Kedokteran UNSRAT Manado jenis karsinoma ini sangat jarang ditemukan, hal inilah yang menarik perhatian kami untuk membahas kasus ini secara lebih rinci.

\section{LAPORAN KASUS}

Seorang perempuan berusia 53 tahun, telah dilakukan histerektomi radikal dengan diagnosis klinis mioma uteri dan diagnosis patologik karsinoma sel skuamosa tanpa keratinisasi dari kerokan endometrium tiga minggu sebelumnya.

Makroskopik, jaringan uterus berukuran $12 \times 11 \times 7 \mathrm{~cm}$ dengan diameter serviks 2 $\mathrm{cm}$ dan dalam rongga endometrium terdapat tumor berukuran $6 \times 5 \times 4 \mathrm{~cm}$ berwarna putih kecoklatan. Terdapat ovarium dan tuba bilateral, serta jaringan omentum dan kelenjarkelenjar getah bening.

Mikroskopik jaringan asal tumor endometrium terdiri dari sel-sel epitel anaplastik yang tersusun difus, dan sebagian membentuk struktur kelenjar dengan perbandingan yang hampir sama (gambar 1). Pada bagian lain terdapat banyak kelompokkelompok sel epitel skuamosa anaplastik (gambar 2). Kelompok sel-sel tumor ini menginvasi sampai ke lapisan dalam miometrium berupa bagian-bagian sel epitel skuamosa anaplastik (gambar 3). Jaringan serviks menunjukkan peradangan kronik. Pada jaringan omentum, kelenjar getah bening, ovarium, dan tuba tidak ditemukan keganasan.

Kesimpulan dari pemeriksaan ini adalah karsinoma adenoskuamosa endometrium derajat dua dengan invasi yang dalam pada jaringan miometrium. 


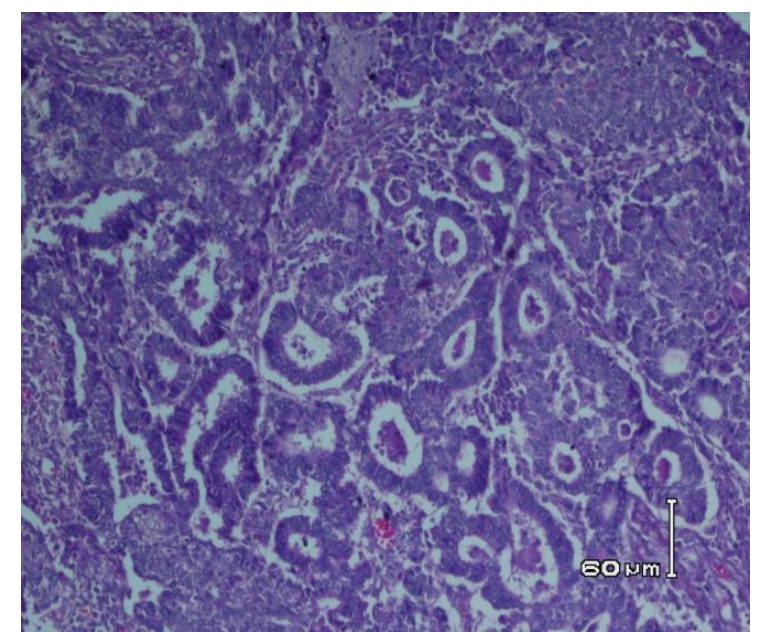

Gambar 1. Komponen kelenjar dan sebagian sel epitel yang tersusun difus

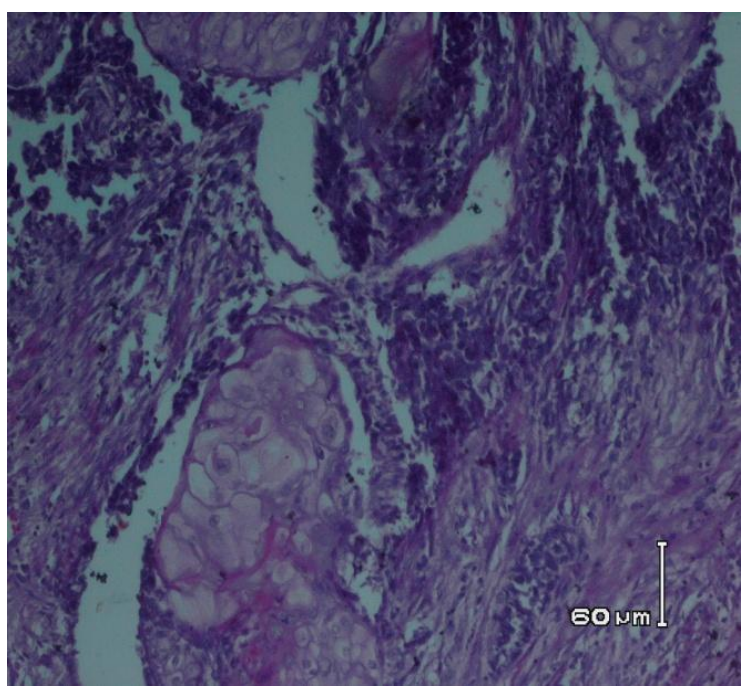

Gambar 2. Komponen skuamosa yang menonjol

\section{PEMBAHASAN}

Keganasan endometrium yang terdiri dari komponen kelenjar dan skuamosa ganas digambarkan sebagai mixed tumor atau karsinoma adenoskuamosa. Istilah yang terakhir lebih disukai karena mixed tumor lebih mengarah pada gabungan keganasan epitel dan stroma. ${ }^{5}$

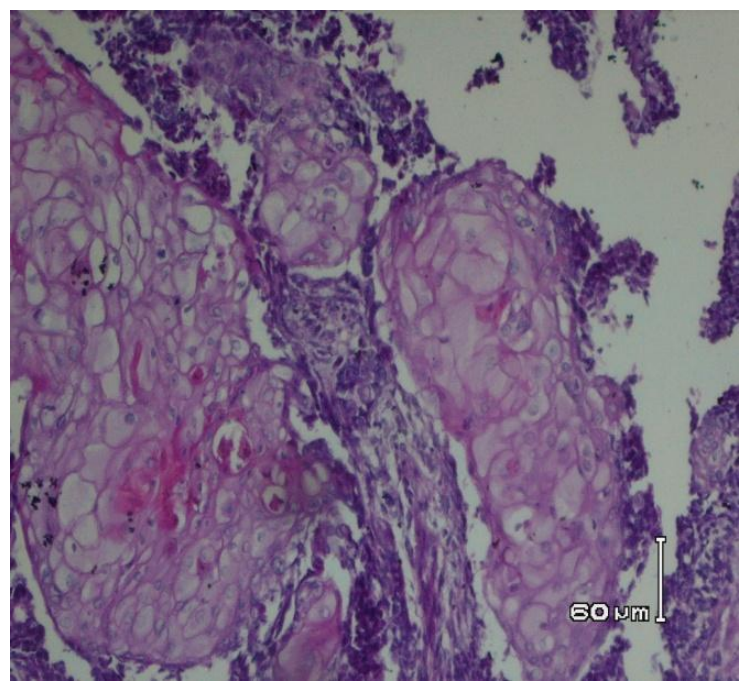

Gambar 3. Invasi komponen skuamosa dan sel epitel yang tersusun difus diantara jaringan miometrium
Pada pemeriksaan awal kasus ini sebagian besar jaringan tumor asal endometrium tampak berupa karsinoma sel skuamosa, namun setelah dilakukan proses pemotongan blok parafin maka ditemukan komponen jaringan adenokarsinoma dalam bentuk kelenjar dan sebagian sel epitel yang tersusun difus dalam jumlah yang hampir 
sama banyak, sesuai dengan gradasi derajat dua.

Kadang-kadang sulit untuk menentukan apakah komponen skuamosa pada $\mathrm{KE}$ ini jinak atau ganas. Hal ini sangat penting dalam menentukan prognosis $\mathrm{KE}$ dimana adenoakantoma mempunyai prognosis baik, sedangkan adenoskuamosa mempunyai pertumbuhan yang lebih progresif. ${ }^{7,8}$ Beberapa peneliti mendapatkan bahwa prognosis dari kedua jenis KE ini tidak berbeda bermakna. Pemeriksaan imunohistokimia menunjukkan bahwa adenoakantoma dan karsinoma adenoskuamosa merupakan satu spektrum metaplasia skua-mosa dalam satu jenis tumor dan bukan merupakan dua kesatuan yang independent. ${ }^{1}$

Pada kasus ini ditemukan KE tipe I. Perbedaan klinikopatologik antara tipe I dan tipe II adalah sesuai dengan perubahan genetik. Tipe I menunjukkan microsatellite instability dan mutasi pada PTEN, PIK3CA, K-Ras, dan B-catenin, sedangkan tipe II memperlihatkan mutasi P53 dan chromosomal instability. ${ }^{3,4}$ Juga pernah dilaporkan kasus karsinoma skuamosa retroperitoneum yang berasal dari metastasis $\mathrm{KE}$ dengan diferensiasi skuamosa lima tahun sebelumnya. $^{7}$

Diferensiasi skuamosa pada KE mempunyai enam bentuk: keratinisasi, morula, hyaline like spherules, undifferentiated large cell nonkeratinizing cells, glassy cells, dan campuran. ${ }^{8}$ Chuan dkk menemukan bahwa bentuk morula secara histologik berbeda dari metaplasia skuamosa; diduga merupakan kelompok sel seperti neuroektodermal yang tidak terinfeksi HPV, sedangkan diferensiasi skuamosa dari $\mathrm{KE}$ dikaitkan dengan infeksi HPV. ${ }^{9}$

Beberapa faktor yang mempengaruhi prognosis KE adalah usia, derajat diferensiasi histologik dan dalamnya invasi miometrium. Menurut derajat diferensiasi maka prognosis derajat tiga lebih buruk dibandingkan dengan derajat satu atau derajat dua. ${ }^{10}$ Blake dkk tidak menemukan dalamnya invasi miometrium sebagai faktor prognosis tersendiri, dan tidak mendapatkan korelasi antara diferensiasi histologik dan dalamnya invasi. ${ }^{11}$

Pada kasus ini walaupun invasi tumor pada miometrium cukup dalam, prognosis pasien ini masih cukup baik karena usia pasien yang relatif muda, jenis diferensiasi histologik tipe I, derajat diferensiasi dua, dan tidak ditemukan adanya pertumbuhan tumor pada serviks, ovarium, tuba, omentum ataupun metastasis pada kelenjar betah bening.

\section{KESIMPULAN}

Telah dilaporkan satu kasus karsinoma adenoskuamosa endometrium pada perempuan berusia 53 tahun. Tiga minggu sebelum dioperasi, dilakukan kerokan endometrium dengan hasil karsinoma sel skuamosa tanpa keratinisasi. Prognosis kasus ini cukup baik karena usia relatif muda, diferensiasi histologik tipe I, derajat diferensiasi dua, dan tidak terdapat metastasis.

\section{DAFTAR PUSTAKA}

1. Rosai J. Uterine carcinoma. Rosai and Ackerman's Surgical Pathology, $9^{\text {th }}$ edition Toronto, Mosby 2004 pp 1585-1594

2. Lurain J.R. Uterine Cancer, in Novak's Gynecology $13^{\text {th }}$ edition, edited by Jonathan S. Berek, MD, MMsc. Tokyo, Lippincott Williams \& Wilkins 2002. pp 1143 - 1172.

3. Prat J, Gallardo A, Cuatrecass M, Catasus L. Endometrial carcinoma; pathology and genetics. Pathology 2007;39(1):72-87

4. Lax SF. Molecular genetic changes in epithelial, stromal and mixed neoplasms of the endometrium. Pathology 2007; 39(1):46-54

5. Haqqani MT, Fox H. Adenosquamous carcinoma of the endometrium. J. Clin.Path 1976;29:959-966 
6. Clement PB, Young RB. Endometrioid carcinoma with squamous metaplasia. Atlas of gynecologic surgical pathology. Philadelphia, Saunder 2008 pp 178-179

7. Liu X, Saiki N, Kohno A, Fujioka M, Hirabayashi K, Komori T, Kobayashi Y, Sunagawa M. Retroperitoneal squamous cell carcinoma: Metastasis from uterine endometrial carcinoma. Radiation Medicine 2000;18(4):267-27

8. Hendrickson MR, Kempson RL. Endometrial hyperplasia, metaplasia and carcinoma. Haines and Taylor Obstetrical and Gynaecological Pathologyy edited by $\mathrm{H}$. Fox $3^{\text {rd }}$ edition volume 1 New York, Churcill Livingstone 1987. pp 334-386

9. Chinen K, Kamiyama K, Kinjo T, Arasaki A, Ilhama Y, Hamada T, Iwasama T.
Morules in endometrial carcinoma and benign endometrial lesions differ from squamous differentiation tissue and are not infected with human papilloma virus. J. Clin. Path 2004; 57:918-926

10.Kuwabara Y, Susumu N, Banno K, Hirao T, Kawaguchi M, Yamagami W, Suzuki N, Aoki D, Nozawa S. Clinical characteristics of prognostic factors in poorly differenttiated (G3) endometrioid adenocarcinoma in Japan. Jpn J Clic Oncol 2005;35(1):23-27

11.Blake P, Lodge N, A'Hern RP. An audit of outcome of adjuvant post-operative radiotherapy for 52 women with stage II carcinoma of endometrium. The British Journal of Radiology. 2000; 73:987-993 